\title{
PERFORMANS AYAM BROILER YANG DIBERI EKSTRAK DAUN KEMANGI (Ocimum basilicum)
}

\author{
Muhammad Muhlisin ${ }^{1)}$, Nuraini ${ }^{2)}$ dan La Ode Ba'a ${ }^{2)}$ \\ ${ }^{1)}$ Alumnus Jurusan Peternakan Fapet Unhalu \\ ${ }^{2)}$ Dosen Jurusan Peternakan Fapet Unhalu
}

\begin{abstract}
ABSTRAK
Penelitian ini bertujuan untuk memperoleh informasi pengaruh pemberian ekstrak daun kemangi terhadap performans ayam broiler. Ayam yang digunakan sebanyak 48 ekor dipelihara selama 28 hari. Ayam dipelihara dalam petak kandang sistem panggung berukuran $0,75 \times 0,75 \times 0,5$ meter sebanyak 12 petak dengan masing-masing petak diisi dengan 4 ekor ayam. Penelitian ini dilaksanakan pada bulan Desember 2012- Januari 2013 di Kandang Peternakan Fakultas Peternakan Universitas Haluoleo Kendari. Penelitian ini menggunakan Rancangan Acak Lengkap (RAL) dengan 4 perlakuan dan 3 ulangan. Perlakuan terdiri atas P0 (Air minum tanpa penambahan ekstrak daun kemangi), P1 (Air minum dengan $5 \mathrm{ml}$ ekstrak daun kemangi/liter air minum), P2 (Air minum dengan $10 \mathrm{ml}$ ekstrak daun kemangi/liter air minum), P3 (Air minum dengan $15 \mathrm{ml}$ ekstrak daun kemangi/liter air minum). Hasil penelitian menunjukkan konsumsi air minum berada pada kisaran $157,56 \pm 3,89-\quad 165,73 \pm 6,79 \mathrm{ml} /$ hari; konsumsi ransum berada pada kisaran 88,70 $\pm 0,99-90,23 \pm 0,34$ gram/hari; pertambahan bobot badan berada pada kisaran 53,46 $\pm 2,10-58,42 \pm 1,56$ gram/hari; konversi ransum berada pada kisaran 1,54 $\pm 0,07-1,66 \pm 0,04$ dengan rataan yang dicapai adalah 1,59. Hasil analisis sidik ragam pemberian ekstrak daun kemangi dalam air minum sampai $15 \mathrm{ml} /$ liter terhadap konsumsi air minum, konsumsi ransum, pertambahan bobot badan dan konversi ransum tidak berpengaruh nyata $(p>0,05)$.
\end{abstract}

Kata kunci: Kemangi, Broiler, Performans.

\begin{abstract}
This experiment was helt to get information about the effect of bacil leaves extracts on broilers performance. Fourty eight broilers were used in this experiment and given treatments during 28 days. The broilers were kept in 12 unit batery cage; $0,75 \times 0,75 \times 0,5 \mathrm{~m}$ for each unit. Each unit of cage was filled with 4 broilers. This experiment was helt during December 2012 until January 2013 in Animal Science Faculty's cage. This experiment used completely randomized design with 4 treatments and 3 replications. The treatments used were P0 (drinking water without bacil leaves extract), P1 (drinking water with $5 \mathrm{ml}$ bacil leaves extract/l drinking water), P2 (drinking water with $10 \mathrm{ml}$ bacil leaves extract/l drinking water), and P3 (drinking water with $15 \mathrm{ml}$ bacil leaves extract/l drinking water). The result of this experiment were drinking water consumption was ranging $157,56 \pm 3,89-165,73 \pm 6,79 \mathrm{ml} /$ day, feed consumption was ranging $88,70 \pm 0,99-90,23 \pm 0,34 \mathrm{~g} /$ day, weight gain was ranging $53,46 \pm 2,10-58,42 \pm 1,56 \mathrm{~g} / \mathrm{day}$, and feed consumption ratio was ranging $1,54 \pm 0,07-1,66 \pm 0,04$ with average 1,59 . The result of variance analysis showed that giving bacil leaves extract until $15 \mathrm{ml} / \mathrm{l}$ drinking water did not give any significant effect $(\mathrm{P}>0,05)$ on drinking water consumption, feed consumption, weight gain and feed convertion ratio.
\end{abstract}

Key words: Bacil, Broilers, Performance.

*) Corresponding authors

\section{PENDAHULUAN}

Peternakan ayam broiler mengalami peningkatan yang signifikan setiap tahunnya. Sebagai salah satu sumber protein hewani, broiler memiliki pertumbuhan daging yang cepat dalam waktu relatif singkat dapat dipanen karena ayam broiler mempunyai sifat genetik yang semakin baik khususnya sifat pertumbuhan. Banyak cara yang dapat digunakan untuk meningkatkan performans ayam broiler. Salah satu cara yang sering dipakai adalah dengan pemberian antibiotik. 
Penggunaan antibiotik mempunyai berbagai keuntungan dan kerugian bagi ternak maupun konsumen yang mengkonsumsi produk ternak tersebut. Keuntungan penggunaan antibiotik diantaranya dapat meningkatkan pertambahan bobot ternak yang signifikan dan mengobati serta mencegah berbagai penyakit sehingga kematian ternak berkurang. Kerugian dari digunakannya antibiotik adalah timbulnya residu antibiotik dan resistensi bakteri terhadap antibakteri. Residu antibiotik dapat membahayakan konsumen karena akan terbawa dalam produk ternak seperti daging, susu, telur dan produk ternak lainnya. Resistensi bakteri dapat menimbulkan kerugian baik bagi manusia maupun ternak karena tingkat kesakitan (morbiditas) dan tingkat kematian (mortalitas) akan meningkat dan biaya produksi menjadi lebih mahal karena harus menggunakan antibiotik yang lebih baru, yang memiliki daya tahan dan daya guna yang lebih banyak terutama yang lebih aman, baik terhadap ternak maupun manusia yang mengkonsumsi produk ternak tersebut.

Penggunaan tanaman herbal sebagai antibiotik merupakan salah satu solusi sebagai pengganti antibiotik sintetik agar tetap menghasilkan produktivitas ayam broiler yang optimal. Salah satu tanaman herbal adalah tanaman kemangi. Kemangi mengandung betakaroten (provitamin A) yang berperan mendukung fungsi penglihatan, meningkatkan respon antibodi (mempengaruhi fungsi kekebalan tubuh), sintesis protein untuk mendukung proses pertumbuhan, dan sebagai antioksidan (Adnyana dan Firmansyah, 2006).

Kemangi juga mengandung komponen non-gizi antara lain senyawa flavonoid dan eugenol, arginin, anetol, boron, dan minyak atsiri. Flavonoid dan eugenol berperan sebagai antioksidan, yang dapat menetralkan radikal bebas, menetralkan kolesterol dan bersifat antikanker. Senyawa ini juga bersifat antibiotik yang mampu mencegah masuknya bakteri, virus, atau jamur yang membahayakan tubuh. Daun kemangi dapat diolah menjadi minyak atsiri. Minyak atsiri dapat mencegah pertumbuhan mikroba penyebab penyakit, seperti Staphylococcus aureus, Salmonella enteritidis, dan Escherichia coli. Minyak atsiri juga dapat menangkal adanya infeksi akibat virus Basillus subtilis, Salmonella paratyphi, dan Proteus vulgaris (Adnyana dan Firmansyah, 2006). Pemanfaatan ekstrak daun kemangi (Ocimum basilicum) dalam air minum diharapkan dapat

meningkatkan performans ayam broiler.

Sebagai salah satu tanaman herbal, kemangi dapat digunakan untuk meningkatkan daya tahan tubuh pada ternak unggas. Hal ini karena kemangi selain sebagai antibiotik dan antioksidan juga tidak menimbulkan residu bagi ternak maupun manusia yang mengkonsumsinya. Rumusan masalah dalam penelitian ini yaitu apakah pemberian ekstrak daun kemangi (Ocimum basilicum) dalam air minum dapat meningkatkan performans ayam broiler.

Tujuan penelitian ini yaitu mengetahui pengaruh pemberian ekstrak daun kemangi (Ocimum basilicum) dalam air minum terhadap performans ayam broiler.

\section{MATERI DAN METODE}

\section{A. Lokasi dan Waktu Penelitian}

Penelitian ini dilaksanakan selama 2 bulan, dimulai dari bulan Desember 2012 sampai Januari 2013 di Kandang Unit Unggas Jurusan Peternakan Fakultas Peternakan Universitas Haluoleo, Kendari

\section{B. Bahan dan Alat}

Bahan yang dipergunakan adalah ayam broiler strain avian SR707 produksi PT. Satwa Utama Raya sebanyak 48 ekor yang dipelihara dari DOC sampai umur 28 hari. Pakan yang diberikan adalah ransum BP-11 Bravo Produksi PT. Charoen Phokphand Indonesia Tbk. Ekstrak daun kemangi yang dibuat tiap 2 hari sekali agar tidak rusak. Air dan ransum diberikan secara ad-libitum setiap hari. 
Peralatan yang digunakan selama pemeliharaan ayam percobaan yaitu 12 unit kandang panggung dengan ukuran 0,75 x 0,75 x 0,5 meter, masing-masing petak berisi 4 ekor ayam. Kandang dilengkapi dengan tempat pakan dan tempat minum dari plastik, serta dilengkapi dengan lampu pijar 40 watt sebagai penghangat dan penerang. Peralatan lainnya yaitu kompor, spoid, saringan, botol, timbangan digital kapasitas 2.000 gram.

\section{Prosedur Penelitian}

Penelitian ini akan dilakukan dengan 2 tahapan, yaitu tahap pemeliharaan selama 7 hari dan tahap pengambilan data dari umur 7 hari sampai 28 hari. Persiapan yang dilakukan sebelum DOC datang yaitu pembuatan kandang panggung dan perlengkapannya, pembersihan petak kandang kemudian disterilisasi menggunakan antiseptik merek Antisep produksi PT. Medion Bandung dengan cara disemprotkan. Setelah kering, pengapuran dilakukan secara merata pada dinding dan alas kandang. Setiap petak kandang diberi nomor perlakuan dan ulangan secara acak. Saat penempatan ayam broiler dalam kandang dilakukan pula pengacakan. Tempat makan dan air minum disiapkan dan dibersihkan sebelum digunakan. Setiap kandang terdapat satu tempat pakan, satu tempat minum dan satu buah lampu 40 watt yang dipasang pada tengah-tengah setiap petak kandang.

DOC yang baru datang diberi larutan gula melalui air minum dengan tujuan untuk menyediakan energi yang langsung dapat diserap oleh saluran alat pencernaan ayam. Setelah umur 7 hari, ekstrak daun kemangi (Ocimum basilicum) dari masing-masing perlakuan disiapkan setiap 2 hari sekali.

Pemberian ransum sebanyak tiga kali dalam sehari yaitu pada pukul 07.00, 12.00 dan 17.00 WITA. Ransum dan air minum diberikan ad libitum sedangkan penambahannya dilakukan setiap hari pada pagi dan sore hari serta malam hari bila diperlukan. Setiap penambahan/penggantian air minum dan ransum, tempat air minum dan pakan tersebut selalu dibersihkan.

Penimbangan bobot badan ayam broiler dilakukan setiap minggu untuk mengetahui kenaikan bobot badan tiap minggunya. Untuk mencegah penyakit, anak ayam divaksinasi menggunakan vaksin ND pada umur 4 hari melalui tetes mata. Vaksin yang digunakan adalah Medivac ND La Sota B1 produksi Bandung. Pembuatan ekstra Daun Kemangi (Ocimum basilicum) sebagaimana tersaji pada Gambar 2.

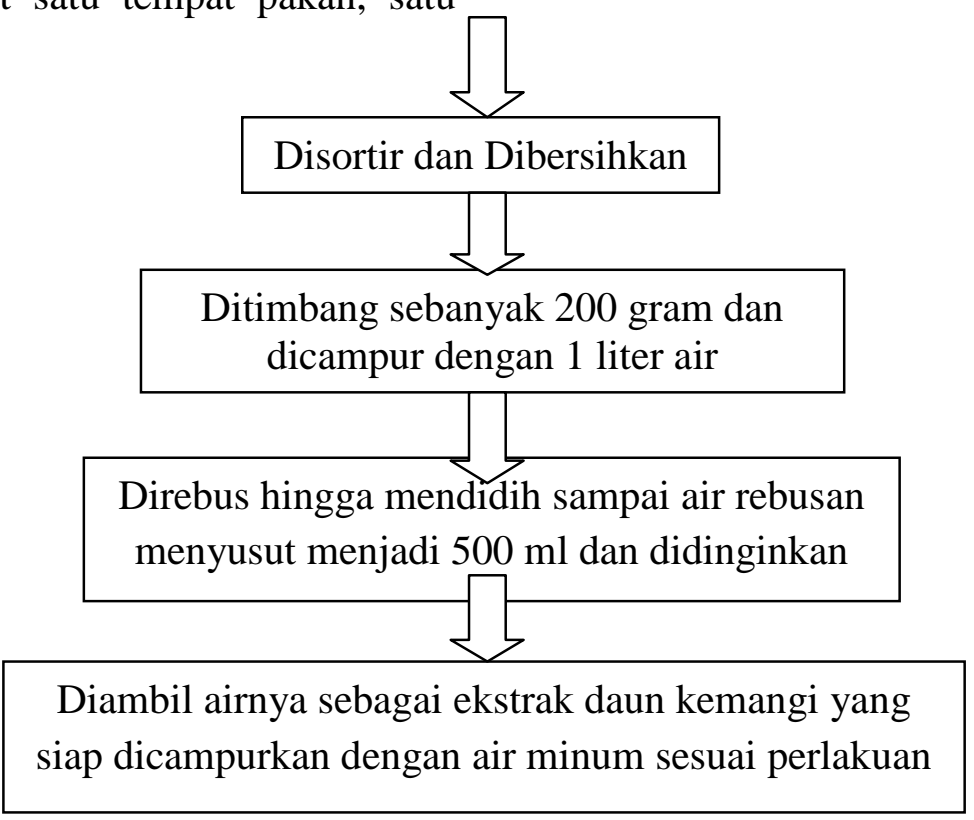

Gambar 2. Diagram alir pembuatan ekstrak daun kemangi (Ocimum basilicum) 


\section{Rancangan Penelitian}

Penelitian ini dilakukan secara eksperimental yaitu dengan memberikan perlakuan berupa pemberian ekstrak daun kemangi (Ocimum basilicum) dalam air minum ayam broiler. Rancangan yang digunakan adalah rancangan acak lengkap (RAL) dengan 4 perlakuan dan 3 ulangan, setiap ulangan terdiri 4 ekor ayam broiler.

Model matematika dari rancangan percobaan mengikuti model matematika Steel dan Torrie (1993), sebagai berikut:

$$
Y i j=+\alpha i+\varepsilon i j
$$

Yij : Nilai pengamatan satuan percobaan ke-j pada perlakuan ke-i.

: Nilai rata-rata sesunguhnya.

$\alpha \mathrm{i}$ : Pengaruh perlakuan taraf pemberian ekstrak daun kemangi

eij : Pengaruh galat percobaan akibat perlakuan ke-i pada satuan percobaan ke-j

Perlakuan yang diberikan adalah ekstrak daun kemangi (Ocimum basilicum) yang dicampurkan ke dalam air minum dengan 4 perlakuan, yaitu:

$\mathrm{P}_{0}=$ Air minum tanpa penambahan ekstrak daun kemangi (EDK);

$\mathrm{P}_{1}=$ Air minum dengan $5 \mathrm{ml} \mathrm{EDK} /$ liter air minum;

$\mathrm{P}_{2}=$ Air minum dengan $10 \mathrm{ml} \mathrm{EDK} /$ liter air minum;

$\mathrm{P}_{3}=$ Air minum dengan $15 \mathrm{ml} \mathrm{EDK} /$ liter air minum.

\section{E. Variabel Penelitian}

Variabel yang akan diuji dalam penelitian ini adalah konsumsi air minum, konsumsi ransum, pertambahan bobot badan (PBB), dan konversi ransum pada ayam broiler.

1. Konsumsi air minum (ml/ekor/hari) diperoleh dengan mengurangi jumlah air minum yang diberikan dengan sisa air minum setiap hari.

2. Konsumsi ransum (g/ekor/hari) diperoleh dengan mengurangi jumlah ransum yang diberikan dengan sisanya setiap minggu dibagi 7 .

3. Pertambahan bobot badan (g/ekor/hari) diperoleh dari pengurangan bobot badan akhir dengan bobot badan awal dibagi lama penelitian.

4. Konversi ransum diperoleh dari jumlah konsumsi ransum dibagi dengan pertambahan bobot badan.

\section{F. Analisis Data}

Data yang diperoleh dianalisis sidik ragam. Apabila hasil yang diperoleh berpengaruh nyata maka akan diuji lanjut berganda Duncan (Gaspersz, 1989).

\section{HASIL DAN PEMBAHASAN}

\section{A. Konsumsi Air Minum}

Air merupakan senyawa penting dalam kehidupan, tidak terkecuali bagi ayam broiler. Hasil pengamatan terhadap konsumsi air minum ayam broiler yang diberi ekstrak daun kemangi dari masingmasing perlakuan dapat dilihat pada Tabel 1.

Tabel 1. Rataan konsumsi air minum ayam broiler (ml/ekor/hari)

\begin{tabular}{|c|c|c|c|c|c|}
\hline \multirow{2}{*}{ Ulangan } & \multicolumn{4}{|c|}{ Perlakuan } & \multirow[t]{2}{*}{ Total } \\
\hline & $\mathrm{P} 0$ & P1 & $\mathrm{P} 2$ & $\mathrm{P} 3$ & \\
\hline 1 & 153,15 & 168,27 & 164,70 & 165,89 & \\
\hline 2 & 159,05 & 170,89 & 161,43 & 161,81 & \\
\hline 3 & 160,48 & 158,04 & 156,79 & 161,73 & \\
\hline Total & 472,68 & 497,20 & 482,92 & 489,43 & 1942,23 \\
\hline Rata-rata & $157,56 \pm 3,89$ & $165,73 \pm 6,79$ & $160,97 \pm 3,97$ & $163,14 \pm 2,38$ & \\
\hline
\end{tabular}


Pada Tabel 1 terlihat bahwa pemberian ekstrak daun kemangi dalam air minum sebanyak $5 \mathrm{ml} /$ liter air minum lebih disukai dari pada pemberian $10 \mathrm{ml}$ dan 15 $\mathrm{ml}$. Hal ini karena semakin tinggi pemberian ekstrak daun kemangi dalam air minum memberikan rasa yang kurang nyaman sehingga konsumsi air minum semakin berkurang.

Hasil analisis ragam menunjukkan bahwa penggunaan ekstrak daun kemangi sampai $15 \mathrm{ml} / \mathrm{liter}$ air minum tidak berpengaruh nyata $(p>0,05)$ terhadap konsumsi air minum ayam broiler. Hal ini menunjukkan bahwa penggunaan ekstrak daun kemangi dalam air minum sampai 15 $\mathrm{ml}$ tidak mengganggu indra penciuman ayam broiler terhadap bau khas kemangi meskipun terdapat rasa dalam air minum. Sebagaimana pernyataan Amrullah (2003), bahwa ayam broiler memiliki sistem perasa berupa gustative atau taste buds untuk mengenali rasa, tetapi indra penciuman (olfactory system) tidak berkembang.

Konsumsi air minum yang diperoleh selama empat minggu penelitian berkisar 157,56-165,73 ml/ekor/hari dengan rata-rata 161,85 ml/ekor/hari lebih tinggi dari hasil penelitian Ahmad dan Elfawati (2008) pada pemberian sari buah mengkudu dimana konsumsi air minum berkisar 106,5-138,1 $\mathrm{ml} / \mathrm{ekor} /$ hari. Jumlah konsumsi air minum pada penelitian ini lebih tinggi 5,02 $\mathrm{ml}$ dari rata-rata NRC (1994) yaitu 156,83 $\mathrm{ml} / \mathrm{ekor} / \mathrm{hari}$. Hal ini menunjukkan bahwa bau dan rasa air minum dari pemberian ekstrak daun kemangi lebih disukai ayam broiler.

Air merupakan senyawa penting dalam kehidupan makhluk hidup, termasuk ayam brioler yang mutlak harus dipenuhi tanpa terkecuali. Pada ayam broiler air minum harus tersedia dalam jumlah yang tidak terbatas, sebab kekurangan air minum pada ayam broiler akan menyebabkan stress dan kematian. Sebagaimana pernyataan Parakkasi (1999), bahwa dua per tiga bagian tubuh hewan adalah air dengan berbagai peranan untuk kehidupan.

\section{B. Konsumsi Ransum}

Konsumsi ransum adalah jumlah ransum yang dimakan setiap ekor ayam broiler apabila makanan tersebut diberikan dalam jumlah tidak terbatas dalam jangka waktu tertentu. Hasil pengamatan terhadap konsumsi ransum ayam broiler yang diberi ekstrak daun kemangi disajikan dalam Tabel 2.

Tabel 2. Rataan konsumsi ransum ayam broiler (gram/ekor/hari)

\begin{tabular}{|c|c|c|c|c|c|}
\hline \multirow{2}{*}{ Ulangan } & \multicolumn{4}{|c|}{ Perlakuan } & \multirow[t]{2}{*}{ Total } \\
\hline & P0 & $\mathrm{P} 1$ & $\mathrm{P} 2$ & P3 & \\
\hline 1 & 89,21 & 89,85 & 89,83 & 89,35 & \\
\hline 2 & 89,98 & 90,50 & 88,28 & 90,38 & \\
\hline 3 & 90,22 & 90,35 & 87,98 & 90,09 & \\
\hline Total & 269,41 & 270,70 & 266,09 & 269,82 & 1076,02 \\
\hline Rata-rata & $89,80 \pm 0,53$ & $90,23 \pm 0,34$ & $88,70 \pm 0,99$ & $89,94 \pm 0,53$ & \\
\hline
\end{tabular}

Keterangan: $\mathrm{P} 0=$ Kontrol, $\mathrm{P} 1=5 \mathrm{ml}$ Ekstrak Daun Kemangi/liter air minum, P2 $=10 \mathrm{ml}$ Ekstrak Daun Kemangi/liter air minum, P3= $15 \mathrm{ml}$ Ekstrak Daun Kemangi/liter air minum.

Rataan konsumsi ransum ayam broiler tertinggi yakni pada perlakuan P1 $(90,23$ gram/ekor/hari) dan yang terendah adalah P2 (88,70 gram/ekor/hari). Hal ini menunjukkan bahwa pemberian ekstrak daun kemangi dalam air minum hingga 15 $\mathrm{ml} / \mathrm{liter}$ air minum belum mampu meningkatkan selera makan ayam broiler.

Hasil analisis ragam menunjukkan bahwa penggunaan ekstrak daun kemangi dalam air minum ayam broiler tidak berpengaruh nyata $(p>0,05)$ terhadap konsumsi ransum ayam broiler. Hal ini 
menunjukkan bahwa pemberian ekstrak daun kemangi sebanyak 5 - $15 \mathrm{ml} /$ liter air minum belum mampu meningkatkan konsumsi ransum ayam broiler. Hasil penelitian yang sama juga dilaporkan oleh Sugiarto (2008), penggunaan tepung kemangi dengan taraf 0-3\% dalam ransum belum mampu meningkatkan konsumsi ransum ayam broiler.

Menurut Parakkasi (1999), konsumsi ransum merupakan jumlah makanan yang dikonsumsi oleh hewan bila makanan tersebut diberikan ad libitum dalam jangka waktu tertentu dan tingkat konsumsi ini menggambarkan palatabilitas. Selanjutnya NRC (1994), menjelaskan bahwa beberapa faktor yang mempengaruhi konsumsi ransum ialah bobot badan ayam, jenis kelamin, aktivitas, suhu lingkungan, kualitas dan kuantitas ransum.

\section{Pertambahan Bobot Badan}

Rataan pertambahan bobot badan harian ayam broiler yang diberi ekstrak daun kemangi dapat dilihat pada Tabel 3.

Tabel 3. Rataan Pertambahan Bobot Badan Ayam Broiler yang Diberi Ekstrak Daun Kemangi Dalam Air Minum (gram/ekor/hari)

\begin{tabular}{|c|c|c|c|c|c|}
\hline \multirow{2}{*}{ Ulangan } & \multicolumn{4}{|c|}{ Perlakuan } & \multirow{2}{*}{ Total (Y) } \\
\hline & $\mathrm{P} 0$ & $\mathrm{P} 1$ & $\mathrm{P} 2$ & $\mathrm{P} 3$ & \\
\hline 1 & 54,99 & 59,66 & 55,85 & 52,60 & \\
\hline 2 & 59,48 & 56,67 & 52,61 & 64,12 & \\
\hline 3 & 60,60 & 58,92 & 51,91 & 53,11 & \\
\hline Total & 175,07 & 175,25 & 160,37 & 169,83 & 680,52 \\
\hline Rata-rata & $58,36 \pm 2,97$ & $58,42 \pm 1,56$ & $53,46 \pm 2,10$ & $56,61 \pm 6,51$ & \\
\hline
\end{tabular}

Keterangan: $\mathrm{P} 0=$ Kontrol, $\mathrm{P} 1=5 \mathrm{ml}$ Ekstrak Daun Kemangi/liter air minum, P2 $=10 \mathrm{ml}$ Ekstrak Daun Kemangi/liter air minum, P3= 15ml Ekstrak Daun Kemangi/liter air minum.

Rataan pertambahan bobot badan ayam broiler dari yang tertinggi hingga terendah yaitu $\mathrm{P} 1=58,42 \pm 1,56$ gr/ekor/hari, $\mathrm{P} 0=$ $58,36 \pm 2,97$ gr/ekor/hari, P3 $=56,61 \pm 6,51$ gr/ekor/hari, P2 = 53,46 $\pm 2,10$ gr/ekor/hari. Hal ini menunjukkan bahwa pemberian ekstrak daun kemangi hingga $15 \mathrm{ml} /$ liter air minum belum mampu meningkatkan pertambahan bobot badan harian ayam broiler. Pertambahan bobot badan harian ayam broiler pada penelitian ini yaitu berkisar 53,46-58,42 gr/ekor. Pemberian ekstrak daun kemangi hingga $15 \mathrm{ml} /$ liter tidak efektif karena menurunkan pertambahan bobot badan harian ayam broiler.

Hasil analisis ragam menunjukkan bahwa penggunaan ekstrak daun kemangi dalam air minum ayam broiler tidak berpengaruh nyata $(p>0,05)$ terhadap pertambahan bobot badan harian ayam broiler. Diduga sebagai akibat dari konsumsi ransum yang tidak berpengaruh nyata. Hasil penelitian yang sama juga dilaporkan oleh Sugiarto (2008), penggunaan tepung kemangi dengan taraf 0 $3 \%$ dalam ransum belum mampu meningkatkan pertambahan bobot badan ayam broiler.

Rasyaf (2002), menyatakan bahwa bobot badan unggas dipengaruhi antara lain oleh kualitas dan kuantitas makanan yang diberikan. Menurut Amrullah (2003), Pertambahan bobot badan ayam broiler yang ideal adalah 400 gr/ekor/minggu atau 57,17 gr/ekor/hari untuk jantan dan untuk betina 300 gr/minggu atau 42,86 gr/ekor/hari. Hasil pengamatan terhadap pertambahan bobot badan harian ayam broiler pada penelitian ini menunjukkan nilai yang lebih tinggi yaitu berkisar antara 53,46 sampai 58,42 gr/ekor/hari atau rata-rata 57,71 gr/ekor/hari. Berdasarkan data pertambahan 
bobot badan menunjukkan bahwa pertambahan bobot badan ayam broiler yang diberi ekstrak daun kemangi masih pada kisaran yang normal.

Pertambahan bobot badan dipengaruhi oleh jumlah pakan yang dikonsumsi. Hal ini sesuai dengan pendapat Gordon dan Charles (2002), terdapat perbedaan bobot badan antara ternak yang diberikan ransum secara ad-libitum dan ternak yang ransumnya dibatasi serta perbedaan antara ternak yang mendapat rasio ransum yang optimal dan ternak yang mendapat ransum tidak optimal.

\section{Konversi Ransum}

Konversi ransum merupakan perbandingan antara unit ransum yang diberikan dengan unit produk yang dihasilkannya. Semakin efisien pemanfaatan ransum bila semakin kecil jumlah ransum yang dibutuhkan untuk menghasilkan tambahan bobot badan yang diinginkan. Rataan konversi ransum ayam broiler umur 28 hari yang diberi ekstrak daun kemangi disajikan pada Tabel 4.

Tabel 4. Rataan Konversi Ransum Ayam Broiler

\begin{tabular}{|c|c|c|c|c|c|}
\hline \multirow[t]{2}{*}{ Ulangan } & \multicolumn{4}{|c|}{ Perlakuan } & \multirow{2}{*}{ Total (Y) } \\
\hline & $\mathrm{P} 0$ & $\mathrm{P} 1$ & $\mathrm{P} 2$ & P3 & \\
\hline 1 & 1,62 & 1,51 & 1,61 & 1,70 & \\
\hline 2 & 1,51 & 1,60 & 1,68 & 1,41 & \\
\hline 3 & 1,49 & 1,53 & 1,69 & 1,70 & \\
\hline Total & 4,62 & 4,64 & 4,98 & 4,81 & 19,05 \\
\hline Rata-rata & $1,54 \pm 0,07$ & $1,55 \pm 0,05$ & $1,66 \pm 0,04$ & $1,60 \pm 0,17$ & \\
\hline
\end{tabular}

Konversi ransum memiliki hubungan erat dengan konsumsi ransum dan pertambahan bobot badan. Konversi ransum pada perlakuan $\mathrm{P} 0, \mathrm{P} 1, \mathrm{P} 2$, dan $\mathrm{P} 3$ berturut-turut adalah 1,$54 ; 1,55 ; 1,66 ; 1,60$. Nilai konversi ransum kontrol lebih kecil dibandingkan perlakuan ekstrak daun kemangi, artinya bahwa penggunaan ekstrak daun kemangi dalam air minum kurang efektif dibandingkan tanpa perlakuan ekstrak daun kemangi.

Hasil analisis ragam menunjukkan bahwa penggunaan ekstrak daun kemangi dalam air minum ayam broiler tidak berpengaruh nyata $(p>0,05)$ terhadap konversi ransum. Ini menunjukkan bahwa pemberian ekstrak daun kemangi dalam air minum tidak mempengaruhi konversi ransum. Hal ini dikarenakan konsumsi ransum dan pertambahan bobot badan yang juga tidak berpengaruh nyata.

Abidin (2003), menyatakan bahwa konversi ransum diartikan sebagai angka banding dari jumlah ransum yang dikonsumsi dibagi dengan berat badan yang diperoleh. Konversi ransum yang diperoleh selama penelitian berkisar 1,54 - 1,66 dengan rata-rata 1,59 . Hasil penelitian yang sama juga dilaporkan oleh Sugiarto (2008), rataan konversi ransum dari penggunaan tepung kemangi dengan taraf 0-3\% dalam ransum adalah 1,59 dan belum mampu meningkatkan performa ayam broiler. Angka konversi ransum pada penelitian ini baik dan efisien sesuai dengan pendapat Rasyaf (2002), menyatakan bahwa konversi ransum yang dianggap baik untuk ayam pedaging umur 1-4 minggu berkisar 1,6 1,84. Semakin rendah konversi ransum adalah semakin baik karena konversi ransum yang rendah menunjukkan efisiensi penggunaan ransum yang baik. Hal ini dikarenakan ransum yang digunakan adalah ransum komersial, dimana kandungan nutrisinya telah mencukupi kebutuhan produksi ayam broiler. 


\section{KESIMPULAN}

Berdasarkan hasil dan pembahasan dapat disimpulkan bahwa pemberian ekstrak daun kemangi dalam air minum belum memberikan dampak positif terhadap peningkatan performans ayam broiler berdasarkan konsumsi ransum, pertambahan bobot badan dan konversi ransum ayam broiler.

\section{DAFTAR PUSTAKA}

Abidin, Z., 2003. Meningkatkan Produktifitas Ayam Ras Pedaging. Agromedia

Pustaka, Jakarta.

Adnyana, I K. dan A. Firmansyah. 2006. Dari pecel lele, obat herba sampai parfum, (online), (http://anekaplanta. wordpress.com/2007/12/22/kemangi -versus-selasih/, diakses pada tanggal 27 November 2012).

Ahmad dan Elfawati, 2008.

Performans ayam broiler yang diberi sari buah

mengkudu (Morinda citrifolia). Jurnal peternakan. 5 (1) :10 - 13.

Amrullah, I K., 2003. Nutrisi Ayam

Broiler. Lembaga Satu Gunung Budi. Bogor.

Anonimous, 2009. Mengapa harus her bal, (online), (http://blogs.unpad.ac.i d/Saula

ndSinaga/? $\mathrm{p}=346$, diakses pada tanggal 27 November 2012).

Asosiasi Obat Hewan Indonesia (ASOHI), 2001. Setengah abad ayam ras di Indonesia. ASOHI. Jakarta.

Charles D.R., 2002. Responses to the thermal environment. In Environmen Problem, A guide to solution (Charles,D.A. and Walker, A.W. Eds.), Nottingham, United Kingdom, pp $1-16$.

Dharmayanti, S., 2003. Berbagai khasiat dau n kemangi, (online), (http://klipingpengetahuan.blogspot.com/2003/01/ berbagai-khasiat-daun-

kemangi.html. Diakses pada tanggal 27 November 2012).
Djunaidi, 2009. Performa dan bobot organ pencernaan ayam broiler yang diberi pakan limbah udang hasil fermentasi bacillus sp. Media Peternakan Vol.32 No.3

Gaspersz, 1989. Metode Perancangan Percobaan. Armico. Bandung.

Gordon, S.H. and D.R. Charles 902. Niche and organik chicken products: Their technology and scientific principles. Nottingham University Press. Definition: III-X, UK.

Her, 2002. Merawat kulit dan melawan bakteri dengan kemangi, (online),(http://www.tempo.co.id/ipt ek/kesehatan/2002/03/3/kes03.html. Diakses pada tanggal 27 November 2012).

Hidayatun, R., 2007. Produksi

ammonia dan hidrogen sulfida ekskreta ayam broiler yang diberi tepung kemangi (Ocimum basilicum) dalam pakan. Skripsi Fakultas Peternakan, Institut Pertanian Bogor, Bogor.

Malik, 2003. Dasar Ternak Unggas.

Universitas Muhammadiyah. Malang.

Murdiati, B. T., 1997. Pemakaian antibiotik dalam usaha peternakan, Wartazoa, Vol. 6, hlm. 18-22.

NRC, 1994. Nutrient Requirement of Poultry. $9^{\text {th }}$ Ed. National Academy of Sciencxe. Washington DC.

Rail, R., 2007. Tumbuh kembang bagianbagian karkas ayam broiler pada jenis kelamin dan tingkat umur yang berbeda. Skripsi Fakultas Peternakan, Universitas Haluoleo, Kendari. (Tidak dipublikasikan).

Parakkasi, A., 1999. Ilmu nutrisi dan makanan ternak ruminan. Penerbit Universitas Indonesia (UI-Press). Jakarta.

Rasyaf, M., 2002. Beternak Ayam

Pedaging. Edisi Revisi. Penebar Swadaya, Jakarta..

Steel, R. G. D. and J. W. Torrie,

1993. Prinsip dan prosedur statistika : suatu pendekatan 
biometrik. Terjemahan oleh B Sumantri. PT. Gramedia Pustaka Utama. Jakarta.

Sugiarto, B., 2008. Performa ayam broiler dengan pakan komersial yang mengandung tepung kemangi (Ocimum basilicum).Skripsi Fakultas Peternakan, Institut Pertanian Bogor, Bogor.

Sutarno, H. dan Atmowidjojo. 2001.

Tantangan Pengembangan dan Fakta Jenis Tanaman Rempah. Prosea Indonesia- Yayasan Prosea, Bogor.

Tobing, V., 2005. Beternak Ayam Broiler Bebas Anti Biotika: Murah dan Bebas Residu. Penebar Swadaya. Jakarta.
Unandar, T., 2003. "Temu Plasma PINTAR 2003". Bahan Seminar Teknis Bersama Elanco Animal Health Indonesia dan PINTAR Lampung. Bandar Lampung. Wahyu, 2004. Ilmu Nutrisi Unggas. Gadjah Mada University Press, Yogyakarta.

Yuningsih, 2008. Keberadaan residu antibiotika dalam produk peternakan (susu dan daging). Disampaikan dalam Lokakarya Nasional Keamanan Pangan Produk Peternakan. Puslitbang Peternakan. Bogor. 